\title{
HAND HYGIENE KNOWLEDGE AMONG HOSPITAL HEALTH WORKERS IN PALEMBANG DURING COVID-19 ERA
}

\author{
Pengetahuan Kebersihan Tangan Petugas Kesehatan Rumah Sakit di Palembang \\ Selama Masa Pandemi Covid-19
}

*Haerawati Idris ${ }^{1}$, Rizma Adlia Syakurah ${ }^{1}$, Dian Safriantini ${ }^{1}$

${ }^{1}$ Faculty of Public Health, Sriwijaya University, Palembang, Indonesia

Correspondence*

Address: JI Palembang Raya, KM.32 Indralaya, Ogan Ilir, Palembang, Indonesia | e-mail: haera@fkm.unsri.ac.id

\begin{abstract}
Background: Hand hygiene is the simplest practical method of preventing cross-infection. Knowledge of hand hygiene plays a vital role in determining adherence to hand hygiene. Nosocomial infection is an infection that occurs in patients in hospital.

Aims: This study aims to analyze the knowledge of health workers regarding hand hygiene in Palembang hospitals during Covid19 era.

Methods: This study used a cross-sectional design with 300 health workers who worked in hospitals in Palembang. They are selected by simple random sampling. Data were collected using online questionnaire during October 2020.

Results: The majority of respondents were female (88.67\%), with the majority age group $30-39$ years $(43.67 \%)$, the majority of respondent came from nurses $(63 \%)$, work in inpatient rooms $(27.33 \%)$. A total of $80.67 \%$ of respondents have received formal training related to hand hygiene. $96 \%$ used alcohol-based hand rub. About $15.33 \%$ of respondents indicated good knowledge, moderate knowledge $(80.33 \%)$, and less knowledge $(4.3 \%)$ regarding hand hygiene. The difference in health workers' profession was significantly related to the level of knowledge about hand hygiene $(p<0.05)$.
\end{abstract}

Conclusion: There are differences in the level of knowledge about hand hygiene in each type of health worker profession

Keywords: hand hygiene, health workers, knowledge, online

\begin{abstract}
Abstrak
Latar Belakang: Kebersihan tangan adalah metode praktis paling sederhana untuk mencegah infeksi silang. Pengetahuan tentang kebersihan tangan memainkan peran penting dalam menentukan kepatuhan terhadap kebersihan tangan. Infeksi nosokomial merupakan infeksi yang terjadi pada pasien di rumah sakit.

Tujuan: Penelitian ini bertujuan untuk menganalisis pengetahuan petugas kesehatan tentang hand hygiene di rumah sakit Palembang di masa Covid-19.

Metode: Penelitian ini menggunakan desain cross sectional dengan 300 tenaga kesehatan yang bekerja di rumah sakit di Palembang. Mereka dipilih menggunakan metode simple random sampling. Data dikumpulkan dengan menggunakan kuesioner online selama bulan oktober 2020. Kuesioner yang digunakan diadopsi dari kuesioner World Health Organization (WHO) dan kuesioner pengetahuan untuk petugas kesehatan edisi revisi 2009. Kami membagikan kuesioner melalui media sosial. Hasil: Responden mayoritas berjenis kelamin perempuan (88,67\%), usia mayoritas 30-39 tahun (43,67\%), sebagian besar responden berasal dari perawat (63\%), bertugas di ruang rawat inap (27,33\%). Sebanyak $80,67 \%$ responden telah mendapatkan pelatihan formal terkait kebersihan tangan, dan $96 \%$ menggunakan antiseptik berbahan dasar alkohol. Tentang kebersihan tangan, sekitar 15,33\% responden menunjukkan pengetahuan baik, pengetahuan sedang sebanyak $80,33 \%$, dan pengetahuan kurang sebanyak $4,3 \%$. Perbedaan profesi petugas kesehatan berhubungan secara bermakna dengan tingkat pengetahuan tentang kebersihan tangan $(P<0,05)$.

Kesimpulan: Adanya perbedaan tingkat pengetahuan tentang kebersihan tangan pada masing masing jenis profesi petugas kesehatan.
\end{abstract}

Kata kunci: kebersihan tangan, pengetahuan, petugas kesehatan, online 


\section{Introduction}

Hand hygiene is the most important and influential step to prevent crossinfection in the hospital. Hand hygiene campaigns were implemented as part of the hospitals' infection control program. Hand hygiene can prevent cross-transmission of microorganisms. Nosocomial infection occurs in patients in hospitals and can affect the quality of health services and cause losses in health services worldwide. In addition, it occurs in health workers or can be a source of vectors when there is contact between health workers and patients. (Rothe, Schlaich, and Thompson, 2013).

Based on the data from World Health Organization, about $1,400,000$ people were suffering from hospital acquired infection every year. It is estimated to be extremely high prevalence in underdeveloped countries (Al Kadi and Salati, 2012). About 7 in 100 hospitalized patients in developed countries and 15 out of 100 hospitalized patients in developing countries will be infected with at least one nosocomial infection (Nejad et al., 2011; Vincent et al., 1995). The intensive care unit and the neonate are areas at risk for this infection as about $30 \%$ of intensive care unit patients have at least one nosocomial infection (Nejad et al., 2011; Vincent et al., 1995).

Transmission of pathogens through healthcare workers' hands is one of the most common modes of transmission of multiresistant organisms and healthcarerelated infections (Zabeeri et al., 2016). Hand hygiene is the simplest practical method for preventing cross-infection (Zabeeri et al., 2016). Knowledge of hand hygiene plays an essential role in determining adherence to hand hygiene. Studies related to knowledge hand hygiene have been explored in various settings, including intensive care units (Mahfouz et al., 2017), heart centers (Din, 2014), university hospitals (Amin et al., 2013), critical care units (Mazi et al., 2013), and public hospitals (Al-Tawfiq et al., 2013; Bukhari et al., 2011). The standard mandates that promote hand hygiene compliance, hand hygiene resources must be made available at critical locations, and behavior change must be supported through education, training, monitoring, feedback, and organizational support (World Health Organization, 2016).

Current Covid-19 pandemics is caused by SARS-CoV-2 virus. This disease appeared in Wuhan, China for the first time in December 2019 and has spread to 113 countries and regions outside China currently (Huang et al., 2020). The virus can be transmitted from human to human, including patients to health workers. Continued exposure by patients supports the transmission of infection to healthcare workers, who are at the front-line of the Covid-19 outbreak (Phan et al., 2019). The World Health Organization (WHO) has recommended patients to practice appropriate hand hygiene to prevent the virus transmission. One of the preventive efforts that need to be optimized during the Covid-19 pandemic maintaining proper hand hygiene (Cavanagh and Wambier, 2020). The World Health Organization (WHO) is very helpful to health workers to ask patients to practice appropriate hand hygiene.

Educating health workers about adherence and effective hand hygiene techniques is very important (Mahfouz et al., 2017). Healthcare worker education has a positive impact on improving hand hygiene and reducing healthcareassociated infection. Identifying hand hygiene knowledge will help build capacity in this regard. A study held in Saudi Arabia reported that lack of knowledge was a stong factor associated with poor hand hygiene perfomance \& education was efective hand hygiene campaign (Al-Tawfiq et al., 2013).

Palembang is one of the cities in Indonesia which has experienced Covid-19 cases. A public hospital in Palembang reported Covid-19 positive cases with 334 people, with the number of deaths 47 people. The high case of Covid-19 potentially due to the vulnerability of health workers. Hand hygiene practice and knowledge are crucial to prevent this problem. Health workers are one of the important human resources in handling Covid cases. Studies related to hand hygiene knowledge among health workers 
at Palembang City Hospital are still limited. This research is expected to become a recommendation to improve compliance with hand hygiene in the hospital. This study aims to analyze the knowledge of health workers regarding hand hygiene in Palembang Hospital.

\section{Method}

This study used a cross-sectional design. We selected the sample by using simple random sampling. The study sample was health workers in the Palembang city hospital-collecting data through online questionnaires and distributed through social media. Three hundred respondents participated in this research during Covid19 era. Data were during October 2020 by filling out a google form questionnaire (https://bit.ly/34WIdBe)

The hand hygiene knowledge questionnaire used for data collection was adopted from the WHO questionnaire with the 2009 revised edition of the knowledge questionnaire for health workers. The questionnaire contained questions about participant's age, gender, profession, department, formal training in hand hygiene, 27 multiple choice questions, and "yes" or "no" to assess hand hygiene knowledge. For each correct answer, one point was counted, and incorrect answers were assigned zero. Overall scores were expressed as a percentage, so an overall score of $>75 \%$ is considered good, $50-74 \%$ moderate, and $<50 \%$ as poor knowledge.

Data analysis were conducted using STATA 12. We provided frequency table of knowledge about hand hygiene in health workers. Quantitative data were summarized as percentages, and then a non-parametric test of significance (chisquare test) was applied on a nominal scale. Person correlation was used with two-tailed p-value and statistical significance was set at $<0.05$.

\section{Result and Discussion}

A total 300 hospital staff completed the questionnaire. The respondents consisted of 189 nurses, 23 midwives, 10 doctors, 13 nutritionists, and 65 technicians. They worked in different units in different hospitals in Palembang. Their units were varied including internal medicine unit, surgery unit, intensive care unit, a mix of medical/ surgical, emergency room, obstetrics, pediatrics, long-term/ rehabilitation, inpatient, outpatient clinics, and other units. Information on the demographic characteristics of the respondents is summarized in Table 1. About $96 \%$ of participants stated that they usually used alcohol-based hand rubs for hand hygiene. $80.67 \%$ of participants had received formal training related to hand hygiene. Most of participant was female $(88.67 \%)$, age $30-39$ (43.67\%), nurse $(63 \%)$, and placed in inpatient unit (27.33\%).

As mentioned in Table 2, about $80.33 \%$ of the participants had moderate knowledge about hand hygiene. Around $4.33 \%$ was classified as low, and only $15.33 \%$ had a good knowledge score.

Table 3 showed bivariate analysis of level of knowledge and the characteristics of health workers. There was a significant difference in the level of knowledge with health professionals $(p<0.05)$. The level of knowledge of hand hygiene for nurses was higher than that of other professions; while the difference was significant $(p=0.042)$. Conversely, there was no relationship between the level of knowledge with gender $(p=0.738)$, individual age $(p=0.738)$, and formal hand hygiene training $(p=0.121)$.

Transmission of the Covid-19 virus in hospitals is one of the main routes for the spread of 2019 novel coronavirus among health workers. However, contact with Covid-19 positive patients can also occur (Araghi et al., 2020). Therefore, hand hygiene is very important for the prevention of Covid-19 among health workers (Malhotra et al., 2020; Pittet et al., 2006). This goal can be achieved by applying an alcohol-based hand rub, washing hands properly with soap and water, and the use of other antiseptic agents (Malhotra et al., 2020).

Some studies have explored that hand hygiene play important role for prevention healthcare association with infection. Hand hygiene is an effective way of controlling nosocomial infections and has a major influence on the incidence of childbed fever. A study reported that hand 
hygiene among healthcare profesional is the most effective method to prevent healthcare associated infections (KuKanich et al., 2013).

This study aims to analyze the knowledge of health workers regarding hand hygiene in Palembang Hospital. We found that the majority of respondents have moderate knowledge. Similar results were obtained in previous studies (Ghadmgahi et al., 2011; Hosseinialhashemi et al., 2015; Maheshwari, 2014). Based on the distribution of professions, most health workers who have good knowledge are nurses. Some studies reported that perfomance among nurses was better than physicians (Ghabrah et al., 2007; Wetzker et al., 2016). .

Table 1. Demographic characteristics of health workers who filled out a questionnaire on knowledge of hand hygiene $(n=300)$

\begin{tabular}{llr}
\hline \multicolumn{1}{c}{ Characteristic } & Answer category & Total $\mathrm{n}(\%)$ \\
\hline Gender & Male & $34(11.33)$ \\
& Female & $266(88.67)$ \\
Age & $\leq 29$ & $115(38.33)$ \\
& $30-39$ & $131(43.67)$ \\
& $40-49$ & $43(14.33)$ \\
Profession & $\geq 50$ & $11(3.67)$ \\
& Nurse & $189(63)$ \\
& Midwife & $23(7.67)$ \\
& Doctor & $10(3.33)$ \\
Department & Nutritionist & $13(4.33)$ \\
& Technician & $65(21.67)$ \\
& Internal medicine & $29(9.67)$ \\
& Surgery & $50(16.67)$ \\
Training & Intensive care unit & $12(4)$ \\
a course about hand washing & Emergency unit & $9(3)$ \\
Using alcohol-based hand rub & Obstetrics & $12(4)$ \\
& Outpatient & $23(7.67)$ \\
& Inpatient & $82(27.33)$ \\
& Isolation & $6(2)$ \\
& Nutritionist & $16(5.33)$ \\
& Others & $61(20.33)$ \\
& Yes & \\
& No. & $242(80.67)$ \\
& & $58(19.33)$ \\
& & $288(96)$ \\
& & $12(4)$ \\
& &
\end{tabular}

Table 2. The comparison of knowledge score according to the participant's characteristics

\begin{tabular}{|c|c|c|c|c|c|c|}
\hline \multirow{2}{*}{$\begin{array}{l}\text { Hand } \\
\text { hygiene } \\
\text { knowledge }\end{array}$} & \multirow{2}{*}{$\begin{array}{c}\text { Total } \\
\text { participant }\end{array}$} & \multicolumn{5}{|c|}{ Profession } \\
\hline & & Nurse & Midwife & Doctor & Nutritionist & Technician \\
\hline Poor & $13(4.33)$ & $6(46.15)$ & 1 (7.69) & $1(7.69)$ & 0 & $5(38.46)$ \\
\hline Moderate & 241 (80.33) & $145(60.17)$ & $19(7.88)$ & $7(2.9)$ & $11(4.56)$ & $59(24.48)$ \\
\hline Good & $46(15.33)$ & $38(82.61)$ & $3(6.52)$ & $2(4.35)$ & $2(4.35)$ & $1(2.17)$ \\
\hline
\end{tabular}


Table 3. Bivariate analysis of the level of knowledge with the characteristics of health workers

\begin{tabular}{|c|c|c|c|c|c|}
\hline \multirow{2}{*}{ Characteristic } & \multirow{2}{*}{ Indicator } & \multicolumn{3}{|c|}{ Level of knowledge } & \multirow{2}{*}{$p$} \\
\hline & & Poor & Moderate & Good & \\
\hline \multirow[t]{2}{*}{ Gender } & Male & $1(2.94)$ & $29(85.29)$ & $4(11.76)$ & \multirow[t]{2}{*}{0.738} \\
\hline & Female & $12(4.51)$ & 212 (79.70) & 42 (15.79) & \\
\hline \multirow[t]{4}{*}{ Age } & $\leq 29$ & $5(4.35)$ & $97(84.35)$ & $13(11.30)$ & \multirow[t]{4}{*}{0.738} \\
\hline & $30-39$ & $6(4.58)$ & $101(77.10)$ & 24 (18.32) & \\
\hline & $40-49$ & $1(2.33)$ & $35(81.40)$ & 7 (16.28) & \\
\hline & $\geq 50$ & $1(9.09)$ & $8(72.73)$ & $2(18.18)$ & \\
\hline \multirow[t]{5}{*}{ Profession } & Nurse & $6(3.17)$ & 145 (76.72) & $38(20.11)$ & \multirow[t]{5}{*}{$0.042^{*}$} \\
\hline & Midwife & $1(4.35)$ & 19 (82.61) & $3(13.04)$ & \\
\hline & Doctor & $1(10)$ & $7(70)$ & $2(20)$ & \\
\hline & Nutritionists & 0 & $11(84.62)$ & $2(15.38)$ & \\
\hline & Technician & $5(7.69)$ & $59(90.77)$ & $1(1.54)$ & \\
\hline Attend a training / & Yes & $8(3.31)$ & $194(80.17)$ & $40(16.53)$ & 0.121 \\
\hline $\begin{array}{l}\text { course about hand } \\
\text { hygiene }\end{array}$ & No & $5(8.62)$ & 47 (81.03) & $6(10.34)$ & \\
\hline
\end{tabular}

Our results show that majority respondent join in the survey was nurses and consisted of midwives, doctors, nutritionists, and technicians as well. They worked in internal medicine unit, surgery unit, intensive care unit, a mix of medical/ surgical, emergency room, obstetrics, pediatrics, long-term/ rehabilitation, inpatient, outpatient clinics, and other units. $80.33 \%$ of the participants had moderate knowledge about hand hygiene. Around $4.33 \%$ is classified as low, and only $15.33 \%$ has a good knowledge score. From the analysis, we found that the average level of knowledge of health workers who have received formal hand hygiene training is better than those who do not, but not significant. This finding is in line with Hosseini's study where training does not affect the level of knowledge (Hosseinialhashemi et al., 2015). This study also revealed a knowledge gap between health workers about hand hygiene. The gap was more visible among technicians, followed by nurses and doctors. The study documented the effect of formal training on hand hygiene knowledge. The study revealed different formal training levels according to profession and gender (Mahfouz et al., 2017). Our results also reported no difference in the level of knowledge in hand hygiene between men and women. The results are the same as several other studies, which reveal that the overall knowledge score does not differ between men and women (Zakeri et al., 2017).

The level of knowledge of hand hygiene for nurses was higher than that of other professions; the difference was significant $(p=0.042)$. Similar gaps in knowledge of hand hygiene were found among health workers during Hajj. Nurses perform better than doctors (Ghabrah et al., 2007). A study in Saudi Arabia shows that lack of knowledge is a strong determinant of poor hand hygiene performance. Education is a key determinant of an effective hand hygiene campaign (AlTawfiq et al., 2013). Table 3 shows the comparison of knowledge score according to the participant's characteristics. We found the disparity of knowlede among health profession. Therefore, we recommend hospitals to increase the knowledge of health workers about hand hygiene based on the type of profession in the hospital which can be carried out through education and training. This may lead to positive perceptions regarding hand hygiene among health workers. WHO also provides the multimodal strategy for 
promoting hand hygiene which can be adopted by hospitals to increase knowledge among health workers. In addition, the hospital can improve strategy for giving motivation, and sanctions to encourage health worker in implementing hand hygiene behavioral.

We assessed the level of hand hygiene knowledge based on the profession with different work units in the hospital. Data collection was carried out in various hospitals to obtain a more representative sample of the sample. But the limitation in this study included our inability to address non-response bias since the study could not provide denominator. Another limitation is the representation of each health worker profession has not been fully achieved. Therefore we recommend this to be explored in future studies.

\section{Conclusion}

Our study demonstrate that most of health worker have received formal training related to hand hygiene. Majority nurse have a good level of knowledge regarding hand hygiene. This study reveals gaps in the knowledge of health workers about hand hygiene based on officers' profession. We recommend that hospitals increase the knowledge of health workers about hand hygiene based on the type of profession in the hospital.

\section{Abbreviations}

WHO: World Health Organization; OR: Odds Ratio; SARS: severe acute respiratory syndrome.

\section{Declarations}

\section{Ethics Approval and Consent Participant}

This study has passed the ethics review from the Ethics Review Center of the Faculty of Public Health, Sriwijaya University

\section{Conflict of Interest}

We declare that we do not conflict with anyone's interest.
Availability of Data and Materials

The availability of data and materials based on demand from journal and readers

\section{Authors' Contribution}

$\mathrm{HI}$ conceptualised the study design and article. DS and RAS prepared the original draft of the manuscript.

\section{Acknowledgment}

Not applicable

\section{References}

Al-Tawfiq, J. A., Abed, M. S., Al-Yami, N., and Birrer, R. B. (2013). Promoting and sustaining a hospital-wide, multifaceted hand hygiene program resulted in significant reduction in health care-associated infections. American journal of infection control, 41(6), pp. 482-486.

Al Kadi, A., and Salati, S. A. (2012). Hand hygiene practices among medical students. Interdisciplinary perspectives on infectious diseases, 2012.

Amin, T. T., Al Noaim, K. I., Saad, M. A. B., Al Malhm, T. A., Al Mulhim, A. A., and Al Awas, M. A. (2013). Standard precautions and infection control, medical students' knowledge and behavior at a Saudi university: the need for change. Global journal of health science, 5(4), pp. 114.

Araghi, F., Tabary, M., Gheisari, M., Abdollahimajd, F., and Dadkhahfar, S. (2020). Hand hygiene among health care workers during COVID-19 pandemic: challenges and recommendations. Dermatitis, 31(4), pp. 233-237.

Bukhari, S. Z., Hussain, W. M., Banjar, A., Almaimani, W. H., Karima, T. M., and Fatani, M. I. (2011). Hand hygiene compliance rate among healthcare professionals. Saudi Med J, 32(5), pp. 515-519.

Cavanagh, G., and Wambier, C. G. (2020). Rational hand hygiene during the coronavirus 2019 (COVID-19) pandemic. Journal of the American Academy of Dermatology, 82(6), e211. 
Din, S. S. (2014). Determinants of hand hygiene non-compliance in a cardiac center in Saudi Arabia. Saudi Med J, 35(2), pp. 147-152.

Ghabrah, T. M., Madani, T. A., Albarrak, A. M., Alhazmi, M. A., Alazraqi, T. A., Alhudaithi, M. A., and Ishaq, A. H. (2007). Assessment of infection control knowledge, attitude and practice among healthcare workers during the Hajj period of the Islamic year 1423 (2003). Scandinavian journal of infectious diseases, 39(1112), pp. 1018-1024.

Ghadmgahi, F., Zighaimat, F., Ebadi, A., and Houshmand, A. (2011). Knowledge, attitude and self-efficacy of nursing staffs in hospital infections control. Journal Mil Med, 13(3), pp. 167-172.

Hosseinialhashemi, M., Kermani, F. S., Palenik, C. J., Pourasghari, H., and Askarian, M. (2015). Knowledge, attitudes, and practices of health care personnel concerning hand hygiene in Shiraz University of Medical Sciences hospitals, 2013-2014. American journal of infection control, 43(9), pp. 1009-1011.

Huang, C., Wang, Y., Li, X., Ren, L., Zhao, J., Hu, Y., Gu, X. (2020). Clinical features of patients infected with 2019 novel coronavirus in Wuhan, China. The Lancet, 395(10223), pp. 497-506.

Israel, S., Harpaz, K., Radvogin, E., Schwartz, C., Gross, I., Mazeh, H.,. Benenson, S. (2020). Dramatically improved hand hygiene performance rates at time of coronavirus pandemic. Clinical Microbiology and Infection, 26(11), pp. 1566.

KuKanich, K. S., Kaur, R., Freeman, L. C., and Powell, D. A. (2013). Evaluation of a hand hygiene campaign in outpatient health care clinics. AJN The American Journal of Nursing, 113(3), pp. 36-42.

Maheshwari, V. (2014). A study to assess knowledge and attitude regarding hand hygiene amongst residents and nursing staff in a tertiary health care setting of Bhopal City. Journal of clinical and diagnostic research: JCDR, 8(8), DC04.
Mahfouz, A. A., Abolyazid, A., Al-Musa, H. M., Awadallah, N. J., Faraheen, A., Khalil, S., Al-Musa, K. M. (2017). Hand hygiene knowledge of primary health care workers in Abha city, South Western Saudi Arabia. Journal of family medicine and primary care, 6(1), pp. 136.

Malhotra, N., Gupta, N., Ish, S., and Ish, P. (2020). COVID-19 in intensive care. Some necessary steps for health care workers. Monaldi Archives for Chest Disease, 90(1).

Mazi, W., Senok, A. C., Al-Kahldy, S., and Abdullah, D. (2013). Implementation of the world health organization hand hygiene improvement strategy in critical care units. Antimicrobial resistance and infection control, 2(1), pp. 15

Nejad, S. B., Allegranzi, B., Syed, S. B., Ellis, B., and Pittet, D. (2011). Healthcare-associated infection in Africa: a systematic review. Bulletin of the World Health Organization, 89, pp. 757-765.

Phan, L. T., Maita, D., Mortiz, D. C., Bleasdale, S. C., and Jones, R. M. (2019). Environmental contact and self-contact patterns of healthcare workers: implications for infection prevention and control. Clinical Infectious Diseases, 69 (Supplement 3), pp. S178-S184.

Pittet, D., Allegranzi, B., Sax, H., Dharan, S., Pessoa-Silva, C. L., Donaldson, L., and Boyce, J. M. (2006). Evidence-based model for hand transmission during patient care and the role of improved practices. The Lancet infectious diseases, 6(10), pp. 641-652.

Rothe, C., Schlaich, C., and Thompson, S. (2013). Healthcare-associated infections in sub-Saharan Africa. Journal of Hospital Infection, 85(4), pp. 257-267.

Vincent, J.-L., Bihari, D. J., Suter, P. M., Bruining, H. A., White, J., NicolasChanoin, M.-H., .Hemmer, M. (1995). The prevalence of nosocomial infection in intensive care units in Europe: results of the European Prevalence of Infection in Intensive 
Care (EPIC) Study. Jama, 274(8), pp. 639-644.

Wetzker, W., Bunte-Schönberger, K., Walter, J., Pilarski, G., Gastmeier, P., and Reichardt, C. (2016). Compliance with hand hygiene: reference data from the national hand hygiene campaign in Germany. Journal of Hospital Infection, 92(4), pp. 328-331.

World Health Organization. (2016). WHO guidelines on hand hygiene in health care. First Global Patient Safety Challenge. Clean Care is Safer Care. Geneva: WHO; 2009.
Zabeeri, N., Amar, N., AbuRuz, M. E., AlQurneh, H., and Mutairi, B. (2016). Perception of health-care workers about hand hygiene and its resources at King Fahad Hospital of University. Int J Med Sci Public Health, 5, pp. 307-312.

Zakeri, H., Ahmadi, F., Rafeemanesh, E., and Saleh, L. A. (2017). The knowledge of hand hygiene among the healthcare workers of two teaching hospitals in Mashhad. Electronic physician, 9(8), pp. 5159. 